\title{
Dissertações de Mestrado
}

\begin{abstract}
DIREITO INTERNACIONAL PRIVADO E DIREITO DO CONSUMIDOR: ADEQUACÃO DOS MÉTODOS DE DIREITO INTERNACIONAL PRIVADO PARA A PROTECÃO DO CONSUMIDOR $^{1}$
\end{abstract}

\section{DANIELA CORREA JACQUES}

\section{RESUMO:}

As relações entre consumidores e fornecedores se transformaram nas últimas décadas, tomando-se comuns casos jurídicos que transcendem fronteiras nacionais, próprios do direito internacional privado. Neste contexto, mister se faz apresentar, analisar e discutir a metodologia proposta por este ramo jurídico e sua aplicação para as relações de consumo. Com base em um caso da jurisprudência brasileira, conhecido como caso Panasonic (REsp. 63.981-SP), em que um turista brasileiro adquire uma máquina filmadora desta marca em Miami, e que o Superior Tribunal de Justiça decide pela aplicação imediata do Código de

\footnotetext{
${ }^{1}$ A banca foi composta pelo Professor Doutor Carlos Silveira Noronha, Professor Titular da Universidade Federal do Rio Grande do Sul e Doutor em Direito pela Universidade de São Paulo; pelo Professor Doutor Paulo Antônio Caliendo Velloso da Silveira, Professor da Universidade do Vale do Rio dos Sinos, Doutor em Direito pela Pontifícia Universidade Católica de São Paulo, e pela Professora Doutora Nádia de Araújo, Professora Titular da Pontifícia Universidade Católica do Rio de Janeiro e Doutora em Direito Internacional pela Universidade de São Paulo. A referida defesa foi presidida pela Professora Doutora Cláudia Lima Marques, Professora Titular de Direito Internacional Privado da Universidade Federal do Rio Grande do Sul, Doutora em Direito pela Universidade de Heidelberg - Alemanha, orientadora do referido trabalho. Data da defesa: 22-01-2004.
} 
Defesa do Consumidor brasileiro, propõe-se o exame das implicações dessa decisão no direito internacional privado do país. Parte-se da análise do método conflitual clássico e a exceção de ordem pública, verificando-se a sua adequação para a proteção do consumidor. Examinam-se algumas tendências na prática jurisprudencial no sentido de ampliar o âmbito de aplicação da lei do foro, bem como analisar as críticas advindas da doutrina, demonstrando a inadequação do método conflitual para regular determinadas relações jurídicas. Propõe-se, assim, o estudo das normas de aplicação imediata como método autônomo do direito internacional privado, no contexto de pluralismo de métodos defendido pelos autores contemporâneos. Examinam-se, ainda, os pressupostos teóricos de sua aplicação e a sua pertinência para a proteção do consumidor. Identificam-se pontos críticos quanto ao seu uso excessivo, podendo implicar um nacionalismo exacerbado e um afastamento dos principios clássicos do direito internacional privado. Procurando-se conjugar alguns aspectos do método conflitual, ainda considerados fundamentais pela doutrina, apresentam-se propostas de superação do unilateralismo das normas de aplicação imediata, com a elaboração de normas conflituais de caráter substancial e a adoção de convenções internacionais. À guisa de conclusões, salienta-se a importância do estudo da problemática dos métodos de direito internacional privado, sugerindo e examinando algumas modificações para o contexto brasileiro, no sentido de acompanhar as demandas sociais, sobretudo na área do direito do consumidor. 